\title{
PERKAWINAN ANAK: Pandangan Ulama dan Tokoh Masyarakat Pamekasan
}

\author{
Umi Supraptiningsih, Erie Hariyanto \\ Institut Agama Islam Negeri Madura, Indonesia \\ E-mail: umistainpamekasan@gmail.com
}

\begin{abstract}
Child marriages as well as the prosession are happen due to the role of both ulama (the Islamic leaders) and the community leaders. This paper aimed at exploring the perception of ulama and the community leaders in line with the factors of child marriage as well as the minimum age of marriage. The descriptive qualitative were implemented in this study. Meanwhile, the data were gathered by conducting observation, interview, and documentation. The first finding of the study is in line with the factors of child marriages. The educational background of the parents and the children, economic factors, cultural factors, and the uncontrolled relationship among teens were regarded to influence the child marriage in Pamekasan. Second, the ulama and the community leader argued that the child marriage should be avoided because it determine the life of the spouse after marriage. It must be considered that marriage is a time to realize the happy family (sakinah). Therefore, maturation is important in attempt to mentally and economically prepare for the marriage. Also, the limitation of marriage is not merely about the minimum age, but also the preoparation and the in-depth understanding of the spouse. Third, there is no clear statement in Alquran regard to the minimum age of marriage. Alquran stated akil baligh as the requirement. Meanwhile, the marriage law stated that minimum age for man is 19 years old and 16 years old for woman. In child protection laws, the minimum age for both man and woman are 18 years old.
\end{abstract}

Keywords: Child marriage; ulama's perspective ; community leader

Abstrak. Perkawinan Anak dapat terjadi karena peran serta dari para ulama atau tokoh masyarakat, begitu pula prosesi perkawinan dengan restu keduanya. Artikel ini bertujuan untuk mengetahui peranan ulama dan tokoh masyarakat Kabupaten Pamekasan dalam terwujudnya perkawinan anak serta pendapat tentang batasan usia perkawinan. Metode penelitian mengunakan pendekatan kualitatif (qualitative approach) dan metode deskriptif, sedangkan teknik pengumpulan data melalui observasi, wawancara, dan dokumentasi. Ada beberapa temuan dalam penelitian ini yaitu pertama Perkawinan anak masih saja terjadi diwilayah Kabupaten Pamekasan, hal ini dilatar belakangi beberapa faktor, yaitu faktor rendahnya pendidikan baik dari orang tua maupun anak, tidak adanya aktifitas atau kegiatan karena selepas dari pesantren atau MA mereka menganggur, faktor ekonomi, faktor budaya atau tradisi, dan faktor pergaulan bebas; kedua Para ulama dan tokoh masyarakat berpendapat bahwa perkawinan anak harus dihindarikarena berdampak pada kelangsungan rumah tangga yang tentunya pasca perkawinan adalah waktu yang panjang untuk mewujudkan rumah tangga yang sakinah. Pendewasaan perkawinan penting karena untuk mempersiapkan mental dan ekonomi dalam sebuah perkawinan. Batasan perkawinan tidak hanya sekedar usia namun persiapan dan pemahaman hak dan kewajiban bagi pasangan yang harus matang. Ketiga Batasan usia pernikahan dalam Al Qur'an dan hadis tidak secara jelas disebutkan hanya menjelaskan akil baliq, sedangkan dalam Undang- Undang Perkawinan usia 19 tahun bagi laki-laki dan 16 tahun bagi perempuan. Dalam UU Perlindungan ana laki-laki dan perempuan sama yaitu 18 tahun ke atas.

Kata Kunci: Perkawinan Anak; Pandangan Ulama; Tokoh Masyarakat

Permalink/DOI: https://doi.org/10.15408/harkat.v15i2.13466 


\section{Pendahuluan}

Maraknya perkawinan anak diberbagai tempat sangat memberikan perhatian besar terutama bagi Kementerian Pemberdayaan Perempuan dan Perlindungan Anak, sebagaimana yang terjadi diberbagai wilayah. Sebagai contoh perkawinan antara pemuda berusia 21 tahun dengan anak Sekolah Dasar yang terjadi di Sulawesi Selatan. Dalam setiap tujuh detik, setidaknya ada satu gadis cilik berusia di bawah 15 tahun menikah, demikian ungkap kelompok penggiat hak anak Save the children dalam laporan terbarunya (BBC, 2018). Jika hal ini benar berarti ada sekitar 4,5 juta anak perempuan menikah setiap tahunnya. Para peneliti dalam mengumpulkan data tentang pernikahan anak bukan hal yang mudah, karena pernikahan tersebut tentunya pelanggaran atas Undang-Undang Perkawinan, sehingga perkawinannya tentunya ilegal.

Perkawinan Anak tidak hanya terjadi di Indonesia saja, baru-baru saja terjadi perkawinan antara laki-laki berasal dari Malaysia yang berusia 44 tahun menikah dengan perempuan Thailad yang berusia 11 tahun. Begitu pula terjadi di Afrika, dimana di Afrika terbagi dalam dua kelompok yaitu kelompok negara yang kaya dan miskin. Untuk kelompok negara yang miskin tingkat perkawinan anak masih sangat tinggi, hal ini menunjukkan bahwa kemiskinan merupakan variabel penting yang beriringan dengan praktikpraktik budaya (BBC, 2018).

Pernikahan Anak dapat terjadi salah satunya tentunya tidak lepas peran serta dari para ulama atau tokoh masyarakat. Begitu pula prosesi perkawinan itu terjadi tidak hanya dilakukan oleh orang tua laki-laki dari si calon mempelai perempuan sebagai wali nikah tetapi juga ada persetujuan ataupun persaksian (sebagai saksi) dari ulama atau sering disebut kyai atau tokoh masyarakat. Faktor yang lain penyebab dari terjadinya perkawinan anak juga tidak lepas dari kultur atau budaya setempat dan juga faktor-faktor lingkungan lainnya.
Pertanyaan besar yang tidak lepas dari praktik perkawinan anak adalah mengapa para ulama dan atau tokoh masyarakat berperan dalam terwujudnya perkawinan anak tersebut. $\mathrm{Hal}$ inilah yang sangat perlu kita gali. Target pada tahun 2030 tidak akan bisa tercapai untuk mengakhiri perkawinan anak jika peran terbesar dalam praktik perkawinan anak tersebut belum menjadi kesepahaman bersama dengan para pembuat kebijakan. Untuk itu sebagai langkah awal perlu digali pandangan dari para ulama dan tokoh masyarakat dalam perkawinan anak di Pamekasan. Selanjutnya dapat dipakai sebagai masukan dalam melakukan pembahasan tentang batasan usia pernikahan.

Masih adanya anggapan di kalangan masyarakat Pamekasan bahwa mempunyai anak perempuan yang tidak segera menikah adalah tabu, malu dan dianggap tidak laku. Padahal anak perempuannya masih bersekolah. Yang juga masih marak terjadi dikalangan masyarakat pedesaan, anak perempuan setelah lulus Sekolah Dasar cukup dimasukkan ke Pesantren hanya untuk menunggu jodoh.

Selain kultur masyarakat, hal lain yang sering terjadi pada masyarakat yang melakukan pernikahan anaknya pada usia anak karena tingginya tingkat kekerasan seksual yang terjadi. Pada tahun 2018 Sampai pada bulan Agustus ini saja Pusat Pelayanan Terpadu Pemberdayaan Perlindungan Perempuan dan Anak (P2TP3A) Kabupaten Pamekasan sudah mendampingi sebanyak 13 kasus korban pemerkosaan yang terlaporkan. Terjadinya kasus pemerkosaan ini dilatar belakangi oleh beberapa faktor, antara lain karena mereka suka sama suka dan karena pengaruh lingkungan.

Peraturan perundang-undangan di Indonesia juga masih belum sinergi, baik dalam pengaturan batasan kedewasaan maupun dalam pengaturan perkawinan. Begitu pula masingmasing daerah masih menjunjung tinggi adat dan tradisi masing-masing yang sangat ditaati, selain adanya pergeseran pergaulan para anak- 
anak dan remaja yang menjadi kekhawatiran orang tua sehingga terlalu cepat untuk menikahkan anak-anak mereka. Penelitian ini bertujuan untuk mengetahui alasan perkawinan anak terjadi di wilayah Kabupaten Pamekasan, untuk mengetahui pandangan ulama dan tokoh masyarakat di Kabupaten Pamekasan tentang perkawinan anak dan yang terakhir adalah untuk menganalisis tinjauan Hukum Islam dan Hukum positif atas perkawinan anak.

\section{Metode}

Metode penelitian yang digunakan adalah Normatif Empiris, dengan menggunakan pendekatan kualitatif (qualitative approach). Selain pendekatan kualitatif yang dipergunakan dalam penelitian ini, peneliti juga menggunakan pendekatan-pendekatan dalam penelitian hukum yaitu pendekatan undang-undang (statute approach), pendekatan kasus (case approach), pendekatan historis (historical approach), dan pendekatan konseptual (conceptual approach) (Marzuki, 2005).

Lokasi penelitian dilakukan di Kabupaten Pamekasan, dengan pengambilan sampel informan tidak didasarkan pada tempat tinggal akan tetapi didasarkan pada ketokohan dan peranannya sebagai ulama dan atau tokoh masyarakat. Sumber data dalam penelitian ini diperoleh dengan menetapkan sebagai informan ulama dan tokoh masyarakat, yang diambil dengan cara acak dibeberapa daerah. Para informan tersebut dianggap cukup untuk mewakili pendapat dari ulama dan tokoh masyarakat se Kabupaten Pamekasan.

Teknik pengumpulan data dalam penelitian ini adalah Wawancara dan dokumentasi. Analisis data dilakukan selama dan setelah pengumpulan data penelitian di lapangan. Teknik analisis data yang dilakukan dalam penelitian ini meliputi empat jenis analisis, yaitu (1) analisis teoritik; (2) analisis hasil wawancara; (3) analisis hasil observasi; dan (4) analisis dokumen. Untuk validitas data temuan, peneliti mengecek temuan dengan menggunakan teknik pengecekan sebagai berikut: Perpanjangan kehadiran Peneliti, Observasi yang diperdalam, Triangulasi, dan Audit Trial Sendiri.

\section{Perkawinan anak masih marak terjadi di wilayah Kabupaten Pamekasan}

Dari hasil penggalian data melalui wawancara baik dengan Ulama dan Tokoh Masyarakat, bahwa di satu sisi perkawinan anak di wilayah Kabupaten Pamekasan masih terus berlangsung, terutama di daerah-daerah pelosok yang belum tersentuh dengan kesadaran pendidikan dan perekonomian yang juga masih sangat rendah. Walaupun secara mayoritas sudah mulai ada penurunan.

Begitu pendidikan yang menjadi indikator utama, maka akan berdampak terhadap banyak hal. Pendidikan menjadikan seseorang lebih matang dalam berfikir dan pernikahan akan selalu direncanakan, sehingga pengelolaan dalam rumah tanggapun juga menjadi matang. Pendidikan tidak hanya untuk anak atau pasangan yang akan menikah namun bagi orang tua juga sangat penting. Terjadi pada orang tua yang tidak berpendidikan, maka cara berfikirnyapun sangat sempit. Orang tua tidak menginginkan yang terlalu jauh, cukup sederhana toh mereka akan kembali ke dapur, sumur dan kasur. Selepas sekolah dasar atau Madrasah Ibtidaiah atau keluar pesantren kecenderungan masyarakat hanya menunggu untuk menikah, hal ini karena mereka tidak mempunyai lagi kegiatan, apa lagi yang ditunggu. Bahkan banyak anjuran setelah lepas dari pendidikan pesantren untuk segera menikah dengan alasan supaya menjaga kesucian dari pergaulan selepas keluar pondok.

Kultur masyarakat setempat terutama di pedesaan bahwa lamaran pertama harus diterima supaya tidak "sangkal". Jika sudah dipinang maka laki-laki punya berbagai alasan untuk mengajak menikah. Pihak perempuan takut 
gagal, istilahnya perempuan itu "Nadheh" apa kata laki-laki, perempuan harus nurut saja. Hal ini juga menjadi penyebab di usia anak-anak mereka sudah segera menikah. Selain itu sangat tabu jika mempunyai anak perempuan tidak ada yang melamar, sehingga orang tua yang tidak didukung dengan pendidikan akan segera menikahkan anaknya tanpa memikirkan resiko yang akan terjadi dikemudian hari. Ada tradisi yang menarik pula, bahwa perkawinan anak terjadi karena atas kehendak orang tua atau kakek. Untuk menjaga hubungan keluarga, dengan istilah "dari pada menjaga pekarangan orang lain lebih baik menjaga pekarangan sendiri”; begitu juga perkawinan anak terjadi karena balas jasa, maksudnya si laki-laki disekolahkan dan dibiayai namun dijodohkan dengan anaknya atau keponakannya.

Faktor ekonomi juga dominan dalam pernikahan anak, Orang tua ingin cepat selesai tanggung jawabnya, supaya ada yang membantu dalam memenuhi kebutuhan ekonomi. Persoalan ekonomi tentunya selaras dengan kondisi kemiskinan yang terjadi pada masyarakat. Berbeda lagi dikalangan orang Arab yang ada di Pamekasan "Kampung Arab", mereka rata-rata SMA sudah menikah yaitu usia 18 tahun untuk laki-laki hal ini lebih berpedoman pada perspektif ulama dulu, dengan asumsi mereka dicoba untuk bisa atau tidak dalam mengelola harta, jika bisa maka diijinkan untuk menikah.

Salah satu sebab perkawinan anak pula juga masih marak terjadi karena materi pembelajaran baik dari Madrasah Tsanawiyah (MTs), Madrasah Aliyah (MA) maupun di pesantren-pesantren masih mengajarkan fikih klasik saja. Begitu pula adanya perbedaan batasan usia anak menurut Fikih, Undangundang Perkawinan dan UU Kependudukan. Sementara masyarakat lebih memilih Fikih karena legitimasi dari Al-Quran dan Hadis, yang tidak terdapat ketentuan batasan usia.

Pergaulan anak-anak yang juga semakin jauh dari norma agama, sehingga orang tua sangat khawatir atas pergaulan tersebut. Dapat dilihat pada kasus yang terjadi pada anak-anak. Kasus kekerasan seksual, persetubuhan baik pelakunya dewasa dan sesama anak-anak sangat marak di Pamekasan. Hal ini merupakan salah satu indikator perkawinan anak terjadi di Pamekasan.

Ada juga yang berpendapat bahwa faktor paling dominan perlaku pernikahan anak di masyarakat pedesaan adalah tokoh masyarakat setempat, mereka mengawinkan baik formal maupun di bawah tangan (sirri). Semua ini tentunya yang lebih dominan kehendak orang tua, bahkan ada yang sudah dijodohkan sejak anak-anak mereka masih kecil. Dan hal ini sudah menjadi kebiasaan di masyarakat pesedaan. Kepercayaan dan penyerahan orang tua kepada Tokoh atau ulama di Madura pada umumnya sangat tinggi dibandingkan dengan penyeraran kepada pejabat yang mempunyai kewenangan yaitu Kantor Urusan Agama. Sering terjadi pergeseran peranan antara penghuru dengan Ulama atau tokoh masyarakat dalam hal prosesi pernikahan. Lebih-lebih jika KUA melakukan penolakan dengan alas an tidak cukup usia pernikahan, maka orang tua langsung meminta ulama atau tokoh masyarakat untuk menikahkan.

\section{Pandangan Ulama dan Tokoh Masyarakat di Kabupaten Pamekasan Tentang Perkawinan Anak}

Pada permasalahan kedua ini, hampir sama pendapat para ulama dan tokoh masyarakat tentang Perkawinan Anak, yang lebih fokus pada batasan usia perkawinan. Pada pembahasan kali ini, ada beberapa pendapat para ulama dan tokoh masyarakat di wilayah Kabupaten Pamekasan tentang Perkawinan Anak, sebagai berikut :

Perkawinan anak seharusnya dihindari, dengan alasan merujuk pada ketentuan yang ada dalam UU No. 1 Tahun 1974 tentang 
Perkawinan karena batasan usia tersebut sudah relevan atau cocok. Justru yang sering diabaikan dalam perkawinan itu adalah kehidupan pasca pernkawinan tentang hak dan kewajiban suami istri sehingga menimbulkan problem yang menyebabkan terjadinya perceraian. Pendapat dari informan yang lain menyatakan bahwa seharusnya perkawinan anak tidak lagi terjadi, walaupun di pesantren sudah diajarkan tentang pemahaman ilmu nifas, dan lain-lain tentang sekitang hak dan kewajiban suami istri tetapi persiapan menikah bukan hanya itu saja, banyak hal yang harus disiapkan terutama mental dan ekonomi. Pendapat ini lebih terfokus pada masyarakat pedesaan, yang sering tidak mempertimbangkan dampak yang akan terjadi dengan adanya perkawinan diusia anak yang banyak terjadi tidak melihat kondisi psikis pada anak jika terjadi problematika dalam rumah tangga yang tentunya juga dari faktor ekonomi. Terutama anak perempuan belum siap dan secara dewasa dapat berfikir positif menghadapi persoalan rumah tangga, lebih-lebih mereka tinggal bersama dengan mertua, sehingga persoalan yang terjadi bukan hanya dengan suami tetapi justru dengan keluarga besar suami.

Perkawinan anak harus segera diakhiri, untuk menghindari berbagai masalah dalam rumah tangga sehingga sampai terjadi perceraian, oleh karena itu tantangan bagi kita adalah adanya peran Perguruan Tinggi atas terjadinya perkawinan anak dan juga peran pesantren yang memang sangat besar dalam perkawinan anak. Selain itu materi ajar atau kurikulum dalam perkuliahan harus segera dilakukan perubahan, karena perkembangan ilmu pengetahuan dan teknologi semakin cepat.

Perkawinan anak jangan hanya dilihat pada ukuran usia pernikahan saja pada pemuda, yang terdapat pada perspektif sadud dariah yang tentunya perlu dikaji secara mendalam dan harus dilihat pada akibatnya. Karena kurang siapnya secara mental dan ekonomi dari pasangan suami istri yang kemudian berakhir dengan perceraian.
Bahwa masing-masing anak tidak sama dalam jenjang kematangan dan kedewasaan, jadi batasan usia anak sampai ia siap menjalani hidup rumah tangga. Secara Agama atau syariah perkawinan anak boleh, karena konstitusi dibangun diatas ruh agama. Walaupun idealnya mesti tunduk pada UU Perkawinan yang melihat maslahat kontektual, dengan batasan usia 25 tahun bagi laki laki dan 20 tahun bagi perempuan. Pelaksanaan pernikahan yang dilakukan secara agama saja tanpa dicatatkan (yang sering disebut perkawinan sirri) karena batasan usia belum cukup menurut UU Perkawinan, maka perkawinannya tetap sah secara syariah namun melanggar UU Perkawinan. Tapi tidak perlu dipidana karena Indonesia negara agama. Yang paling penting pemahaman dan penyadaran orang tua dan wawasan masyarakat bahwa jaman berubah dan hukum Islam juga dinamis kontekstual.

Pandangan terhadap pemenuhan ekonomi rumah tangga bahwa usia kematangan dalam menikah untuk laki-laki adalah kematangan dalam mengelola harta, dan usia bagi perempuan dibawahnya. Jika berpedoman pada perspektif Tafsir Ulama Klasik yang mengikuti Nabi Muhammad, SAW, laki-laki 25 tahun dan perempuan dibawahnya dengan selisih antara 5 tahun sampai 6 tahun. Usia 25 tahun bagi lakilaki adalah diharapkan sudah mandiri untuk menafkahi (sebenarnya usia matang untuk lakilaki adalah 40 tahun yaitu kematangan secara pemikiran). Adanya perbedaan usia laki-laki dan perempuan dimaksudkan, laki- laki sebagai kepala keluarga harus lebih matang untuk menjadi Imam dalam rumah tangga, dia harus melindungi, mengayomi, memberi rasa damai bagi keluarga. Jika istri melakukan hal-hal yang tidak baik, suami wajib memberikan nasehat, namun jika usia mereka sama bisa terjadi tidak ada yang mau mengalah dan sama-sama untuk menang sendiri.

Islam memang tidak ada batasan usia, jika dilihat dalam nas-nas tapi di Indonesia ada 
batasan untuk menentukan tanda-tanda akil balig. Usia 15 tahun pasti sudah akil baliq, perempuan haid diusia 12 tahun ini terdapat dalam kitab- kitab fikih. Untuk pernikahan anak informan ini lebih melihat pada ketaatan yang diatur dalam UU karena sebagai abdi Negara yang harus menjalankan perintah UU. Untuk batasan usia menikah sebaiknya tetap pada aturan yang ada yaitu 17 perempuan dan 19 laki-laki itu sudah ideal, jika akan dinaikkan menurut saya terlalu berat, melihat banyaknya kasus-kasus pada remaja sekarang. Persiapan yang harus juga dilakukan adalah mental, dan pendidikan agama ini menjadi keharusan.

Perkawinan anak, dengan menggunakan pandangan sosiologis, karena selama ini masih banyak yang melakukan perkawinan dibawah umur, walaupun mereka sebenarnya belum siap untuk menikah. Mereka menikah hanya nafsu saja, belum mempunyai visi yaitu untuk membentuk keluarga sakinah belum mampu. Di usia 21 tahun saja itu belum mampu, contohnya saja mahasiswa yang rata-rata usia diatas 21, namun untuk membentuk keluarga belum matang. Memang patut jika usia nikah itu dinaikkan dari aturan UU Perkawinan yaitu idealnya 20 tahun bagi perempuan dan 25 bagi laki-laki.

Pendapat yang lain dari informan, menyatakan bahwa Perkawinan anak secara hukum tidak ada larangan karena dalil agama tidak dilihat dari umur tapi baliq. Pandangan para ulama, wanita dibawah umur titik tekannya ada pada orang tua, sedangkan jika dewasa perannya tinggal 75 persen sehingga jika dijodohkan bisa melakukan penolakan. Pernikahan harus ada persiapan, bagi laki-laki ukurannya adalah materi atau harta sebanyak hasil kerja selama 8 tahun (kisah Nabi Musa AS) atau memiliki unta sebanyak 100 ekor sebagai mahar. Sedangkan bagi perempuan adalah kematangan dalam agama dalam arti membina rumah tangga. Pasca pernikahan harus diketahui bahwa hak dan kewajiban orang tua sudah pindah kepada suami. Jika suatu perkawinan yang dilakukan belum memenuhi syarat, cenderung menimbulkan permasalahan, karena tidak sesuai dengan usia matang, maka akan menimbulkan persoalan dalam keluarga. Yang harus disiapkan adalah segala hal yang berkaitan dengan perekonomian, pendidikan baik spiritual maupun formal, dan kematangan berpikir.

Usia pernikahan yang dibawah umur, baik menurut fikih dan undang- undang, adalah Baligh dan memiliki kecakapan untuk melaksanakan kewajiban dan hak sebagai suami istri. Penyebab utamanya adalah ketidaktegasan UU Perkawinan tentang perkawinan anak, jika ada UU yang menyatakan bahwa perkawinan anak adalah tidak sah maka tidak ada masyarakat yang melakukan penafsiran sehingga adanya penyimpangan, jika ada ketegasan ini, maka ini bisa masuk dalam Kaidah "Hukmul Hakim Yulzim wa Yarfa'u al-Khilaf. Orang Tua harus memberikan penyadaran, bahwa pernikahan bukan sekedar laki-laki dan perempuan, tetapi ada hak dan kewajiban. Kemudian kepada anak bahwa pernikahan bukan sekedar pelampiasan seksual, jangan sampai perkawinan anak disebabkan karena pergaulan yang bebas, dan perlu diberikan pengetahuan hak dan kewajiban.

\section{Tinjauan Hukum Islam dan Hukum Positif atas Perkawinan Anak}

Dalam literatur Fikih Madzhab Imam Syafii, Kitab Al-Taqrib karya Ahmad Bin Husein (Abu Syuja') dan syarahnya yaitu Kitab Fathul Qorib al- Mujib, karya Syekh Muhammad bin Qosim), ditegaskan bahwa pernikahan menurut hukum Islam adalah sunah, laki-laki disunnahkan menikah 4 wanita dengan berbagai persyaratan yang ketat, syaratnya adalah balig (hal ini menjadi batasan umur yang tidak bisa ditawar dalam hukum Islam), berakal, muslim dan merdeka.

Majelis Ulama Indonesia (MUI) pernah mengeluarkan fatwa tentang pernikahan di usia anak. Menurut MUI, dalam literatur fikih Islam 
tidak terdapat ketentuan secara eksplisit mengenai batasan usia pernikahan baik itu batasan minimal maupun maksimal. Allah SWT berfirman, "Dan kawinkanlah orang- orang yang sendirian di antara kamu dan orang-orang yang layak dari hamba- hamba sahayamu yang lelaki dan yang perempuan." (QS an-Nur [24] :32). Menurut sebagian ulama, yang dimaksud layak adalah kemampuan biologis. Artinya memiliki kemampuan untuk menghasilkan keturunan.

Walaupun demikian, hikmah disyariatkannya pernikahan adalah menciptakan keluarga yang sakinah serta dalam rangka memperoleh keturunan. Menjaga keturunan (hifz al-nasl) adalah salah satu tujuan diturunkannya syariat Islam. Kemampuan menjaga keturunan tersebut juga dipengaruhi usia calon mempelai yang telah sempurna akalnya dan siap melakukan proses reproduksi.

Menurut syariat Islam, usia kelayakan pernikahan adalah usia kecakapan berbuat dan menerima hak (ahliyatul ada' wa al-wujub). Islam tidak menentukan batas usia namun mengatur usia baligh untuk siap menerima pembebanan hukum Islam. MUI mempertimbangkan semua pandangan ulama soal hukum pernikahan dini. Ada beberapa perbedaan pendapat soal kebolehan pernikahan ini. Jumhur ulama fikih, sebenarnya tidak mempermasalahkan soal pernikahan usia dini. Sementara itu Ibn Hazm memilih hukum nikah usia dini pada lelaki dan perempuan. Pernikahan usia dini pada perempuan yang masih kecil oleh orang tua atau walinya diperbolehkan. Sementara pernikahan anak untuk anak lelaki tidak diperbolehkan.

Pendapat berbeda diungkapkan oleh Ibnu Syubrumah dan Abu Bakar al- Asham. Menurut mereka, pernikahan dini hukumnya terlarang. Pendapat yang terdapat dalam Fathul Bari ini menyebutkan kebolehan nikah dini merujuk pada pernikahan Nabi Muhammad, SAW dengan Aisyah, maka hal tersebut adalah sebuah kekhususan. Praktik pernikahan tersebut hanya dikhususkan untuk Nabi Muhammad, SAW dan tidak untuk umatnya. Berdasar beberapa pertimbangan tersebut, MUI memutuskan pernikahan anak pada dasarnya sah sepanjang telah terpenuhinya syarat dan rukun nikah. Namun hukumnya akan menjadi haram jika pernikahan tersebut justru menimbulkan mudharat (Republika, 2014).

Kedewasaan usia merupakan salah satu indikator bagi tercapainya tujuan pernikahan. Tujuan pernikahan adalah kemashlahatan hidup berumah tangga dan bermasyarakat serta jaminan bagi kehamilan. MUI memutuskan demi kemashlahatan, ketentuan pernikahan dikembalikan kepada ketentuan standardisasi usia merujuk UU No 1 Tahun 1974 tentang Perkawinan.

Tinjauan Hukum Positif tentang perkawinan anak, menyikapi ketentuan dalam UU No. 1 Tahun 1974 tentang Perkawinan, telah memberikan aturan dalam pasal 7 , yang berbunyi sebagai berikut : pertama Perkawinan hanya diizinkan jika pihak pria sudah mencapai umur 19 (sembilan belas) tahun dan pihak wanita sudah mencapai umur 16 (enam belas) tahun.

- Dalam hal penyimpangan terhadap ayat (1) pasal ini dapat meminta dispensasi kepada Pengadilan atau Pejabat lain yang ditunjuk oleh kedua orang tua pihak pria maupun pihak wanita.

- Ketentuan-ketentuan mengenai keadaan salah seorang atau kedua orang tua tersebut dalam Pasal 6 ayat (3) dan (4) Undang-undang ini, berlaku juga dalam hal permintaan dispensasi tersebut ayat (2) pasal ini dengan tidak mengurangi yang dimaksud dalam Pasal 6 ayat (6).

Ketentuan dalam UU Perkawinan tersebut yang memberikan batasan minimal usia perkawinan tentunya perlu ditinjau kembali karena bertentangan dengan UU No. 23 Tahun 2002 yang telah dirubah dengan UU No. 35 
Tahun 2014 tentang Perlindungan Anak. Batasan kedewasaan dalam UU Perlindungan Anak adalah usia 18 tahun, sebagaimana dinyatakan dalam pasal 1 ayat (1) yang berbunyi "Anak adalah seseorang yang belum berusia 18 (delapan belas) tahun, termasuk anak yang masih dalam kandungan". Jika kita cermati dalam UU Perlindungan Anak, maka perkawinan yang dilakukan oleh anak yang belum mencapai 18 tahun, walaupun dalam UU Perkawinan telah memenuhi syarat usia perkawinan, namun masih tergolong perkawinan anak.

Meninjau kembali hasil putusan Mahkamah Konstitusi (MK) Nomor 22/PUU$\mathrm{XV} / 2017$ yang telah mengabulkan sebagian gugatan uji materi Undang Undang Nomor 1 Tahun 1974 tentang Perkawinan, terkait batas usia perkawinan anak. Dalam pertimbangannya, MK menyatakan perbedaan batas usia perkawinan antara laki-laki dan perempuan menimbulkan diskriminasi. Yang amar putusannya berbunyi : "Mengadili, mengabulkan permohonan para pemohon untuk sebagian," Ketentuan tentang batas usia perkawinan sebelumnya digugat sekelompok warga negara yang merasa dirugikan dengan perbedaan batas usia laki-laki dan perempuan. Dalam pasal 7 ayat (1) UU Perkawinan mengatur batas minimal usia perkawinan laki-laki adalah 19 tahun sementara perempuan adalah 16 tahun. MK menilai batasan usia tersebut bertentangan dengan UUD 1945 dan UU Perlindungan Anak. Dalam UU Perlindungan Anak menyebutkan bahwa anak-anak adalah mereka yang berusia di bawah 18 tahun. Sehingga siapapun yang masih berusia di bawah 18 tahun masih termasuk kategori anak-anak. "Dengan demikian batas usia yang diatur dalam UU Perkawinan masih berkategori sebagai anak," Perkawinan anak sangat mengancam dan berdampak negatif terutama pada aspek kesehatan. Selain itu, peluang terjadinya eksploitasi dan ancaman kekerasan juga lebih tinggi pada anak. Perbedaan pada batasan usia juga menimbulkan perbedaan perlakuan antara laki-laki dan perempuan. Batasan usia minimal 19 tahun yang diterapkan bagi laki-laki dinilai memberikan rentang waktu yang lebih panjang sebagai anak ketimbang perempuan.

Perkawinan anak juga akan berdampak buruk pada pendidikan anak, hal ini jelas bertentangan dengan semangat pasal 31 UUD 1945 yang menyebutkan bahwa setiap warga negara berhak mendapatkan pendidikan dasar 12 tahun. Jika seorang perempuan menikah pada usia 16 tahun, maka mereka akan kehilangan hak pendidikan dasar 12 tahun. Sedangkan hak memperoleh pendidikan merupakan hak konstitusional yang wajib dinikmati setara antara perempuan dan laki-laki.

Perlu dipertegas kembali sesuai dengan kompetensi yang dimiliki oleh MK, bahwa MK tidak memiliki kewenangan untuk menentukan batasan usia perkawinan sehingga hasil putusan MK tersebut menjadi bola yang harus ditangkap oleh Dewan Perwakilan Rakyat (DPR) yang mempunyai kewenangan sebagai pembentuk UU. Sehingga MK memberi waktu kepada DPR paling lama tiga tahun untuk segera melakukan perubahan UU Perkawinan khususnya pada batasan usia minimal pernikahan bagi perempuan sebagaimana diatur dalam pasal 7 .

Selain UU Perkawinan dan putusan MK sebagai landasan ketentuan hukum positif di Indonesia dalam pengaturan batasan usia menikah, UU Perlindungan Anak, sangat tegas telah melakukan pencegahan dalam hal terjadinya perkawinan anak, sebagaimana dinyatakan dalam Pasal 26 yang berbunyi pertama Orang tua berkewajiban dan bertanggung jawab untuk : (a) mengasuh, memelihara, mendidik, dan melindungi anak; (b) menumbuhkembangkan anak sesuai dengan kemampuan, bakat, dan minatnya; dan (c) mencegah terjadinya perkawinan pada usia anakanak. Kedua Dalam hal orang tua tidak ada, atau tidak diketahui keberadaannya, atau karena suatu sebab, tidak dapat melaksanakan 
kewajiban dan tanggung jawabnya, maka kewajiban dan tanggung jawab sebagaimana dimaksud dalam ayat (1) dapat beralih kepada keluarga, yang dilaksanakan sesuai dengan ketentuan peraturan perundang- undangan yang berlaku.

Pada bunyi pasal 26 ayat (1c) yang jelasjelas orang tua harus melakukan pencegahan terjadinya perkawinan pada usia anak, jika justru orang tua yang melakukan atau mendorong terjadinya perkawinan anak, maka orang tua dapat dikenakan sanksi secara hukum.

\section{Penutup}

Perkawinan anak masih saja terjadi diwilayah Kabupaten Pamekasan, hal ini dilator belakangi beberapa factor, yaitu factor rendahnya pendidikan baik dari orang tua maupun anak, tidak adanya aktifitas atau kegiatan, faktor ekonomi, faktor budaya atau tradisi, dan factor pergaulan bebas. Para ulama dan tokoh masyarakat berpendapat bahwa perkawinan anak harus dihindari karena berdampak pada kelangsungan rumah tangga yang tentunya pasca perkawinan adalah waktu yang panjang untuk mewujudkan rumah tangga yang sakinah. Pendewasaan perkawinan penting karena untuk mempersiapkan mental dan ekonomi dalam sebuah perkawinan. Batasan perkawinan tidak hanya sekedar usia namun persiapan dan pemahaman hak dan kewajiban bagi pasangan yang harus matang. Batasan usia pernikahan dalam Al Qur'an dan hadis tidak secara jelas disebutkan hanya menjelaskan akil baliq, sedangkan dalam hokum positif lebih pada ketentuan pasal 7 UU Perkawinan yaitu usia 19 tahun bagi laki-laki dan 16 tahun bagi perempuan. Selain itu dalam UU Perlindungan anak tidak lagi berbicara laki-laki dan perempuan namun sama yaitu usia kedewasaan adalah 18 tahun ke atas. Pasal 26 UU Perlindungan anak dengan tegas mencegah terjadinya perkawinan anak.

\section{Daftar Pustaka}

CHild Marriage: Lastest trends and future prospects, UNICEF, 2018 Djamilah, Reni Kartikawati, Dampak Perkawinan Anak di Indonesia, JurnalStudi Pemuda • Vol. 3, No. 1, Mei 2014

Hadi, Sutrisno, Metodologi Research, Yogyakarta: Andi Affist, 1990

Eddy Fadlyana (Shinta Larasaty Bagian Ilmu Kesehatan Anak FK Universitas Padjajaran/RS Dr Hasan Sadikin Bandung), Pernikahan Usia Dini dan Permasalahannya, Jurnal Sari Pediatri, Vol. 11, No. 2, Agustus 2009

J. Moleong, Lexy, Metodologi Penelitian Kualitatif, Bandung: Remaja

Rosdakarya, 1990

M. Friedman, Lawrence, American Law : An Introduction, W.W. Norton \& Company, New York, 1984.

M. Hadjon, Philipus, dan Tatiek Sri Djatmiati, Argumentasi Hukum, Yogyakarta: Gajah Mada University Press, 2005

Marzuki, Peter Mahmud, Penelitian Hukum, Jakarta : Kencana Prenada Media Group, 2005,

Spradley, J.P. Participant Observation. New York: Holt, Rinehart, and Winston, 1980

Muhadjir, Noeng, Metode Penelitian Kualitatif, Yogyakarta: Rake Sarasin, 1996 Nonet, Phillippe dan Philip Selznick, Hukum Responsif, diterjemahkan dari Law and Society in Transilition oleh Raisul Muttaqien, Bandung : Nusamedia, 2007

Rohmi, Mayadina Musfiroh (Universitas Islam Nahdlatul Ulama Jepara), Pernikahan Dini dan Upaya Perlindungan Anak di Indonesia ,Jurnal Hukum dan Syari'ah, Vol. 8, No. 2, 2016,

Soekamto, Soerjono, Pengantar Penelitian Hukum ,Jakarta : UI Press, 1988.

Spradley, J.P. Participant Observation. New York: Holt, Rinehart, and Winston, 1980

Sensus Penduduk Tahun 2007, Badan Pusat Statistik Kab. Pamekasan Tahun 2008/2009

Supraptiningsih, Umi, Penerapan UU N0. 23 Tahun 2002 Tentang Perlindungan Anak (Studi Kasus Terhadap Anak Yang Berhadapan Dengan Proses Hukum)", Asy- 
Jurnal Harkat : Media Komunikasi Gender, 15 (2), 2019

Syir'ah - Jurnal Ilmu Syari'ah , (Vol 44 No. II, 2010), Terakreditasi SK No. 43/DIKTI/Kep/2008

Supraptiningsih, Umi. "Kesiapan Penegak Hukum Di Kabupaten Pamekasan Dalam Pemberlakuan Uu No. 11 Tahun 2012 Tentang Sistem Peradilan Pidana Anak." (2014).

Utsman, Sabian, Menuju Penegakan Hukum Responsif, Yogyakarta: Pustaka Pelajar, 2008

, Menuju Penegakan Hukum Responsif Konsep Phillippe Nonet dan Philip Selznick Perbandingan Civil Law System dan Common Law System Spiral Kekerasan dan Penegakan Hukum, (Yogyakarta : Pustaka Pelajar, 2008)
Laporan Penelitian, Program Studi Kajian Gender Sekolah Kajian Strategik Dan Global Universitas Indonesia Bekerja Sama Dengan Kementerian Pemberdayaan Perempuan Dan Perlindungan Anak Republik Indonesia, November 2016

UU RI No 23 Tahun 2002 Ttg. Perlindungan Anak Serta Perubahannya 2014.” Accessed July 20, 2019.

http://humanrightspapua.org/resources/nlaw/1 69- uu-ri-no-23-tahun-2002-ttgperlindungan-anak-dan-perubahan. www.bbc.com/indonesia/majalah-37820063 diakses tanggal 8 Agustus 2018 